\title{
PELATIHAN BAHASA INGGRIS BAGI WARGA BELAJAR PAKET C TIGAWASA PKBM WIDYA AKSARA
}

\author{
N. P. A. Hervina Sanjayanti ${ }^{{ }^{*}}$, P. Bayoe Mahaputra ${ }^{2}$ \\ ${ }^{1 *}$ Jurusan Teknik Komputer, Politeknik Ganesha Guru \\ ${ }^{2}$ Jurusan Manajemen Informatika, Politeknik Ganesha Guru \\ ${ }^{*}$ Corresponding author : \\ E-mail: sanjayantihervina@gmail.com
}

Diterima 30 April 2018, Disetujui 5 Mei 2018

\begin{abstract}
ABSTRAK
Pelatihan bahasa Inggris bagi warga Desa Tigawasa bertujuan untuk mengembangkankan kemampuan berkomunikasi dalam Bahasa Inggris yang diarahkan kepada kepiawaian pesertanya melakukan berbicara dan menulis dalam Bahasa Inggris. Setiap peserta dilatih untuk berbicara dan menulis dengan menggunakan Bahasa Inggris. Metode yang digunakan yaitu penugasan dan latihan, dimana para peserta ditugaskan untuk berlatih berbicara bahasa Inggris mengenai percakapan dengan wisatawan asing dan menulis dalam Bahasa Inggris. Pelatihan Bahasa Inggris ditekankan pada kemampuan peserta menyatakan ide dengan kata-kata, atau kemampuan mengingat suatu konsep, atau prinsip tertentu dan menyatakan kembali dengan kata-kata yang terangkai dalam sebuah kalimat.
\end{abstract}

Kata kunci: Pelatihan, Bahasa Inggris, Warga Desa Tigawasa Paket C.

\section{ABSTRACT}

The English training for Tigawasa Village residents is aimed at developing skills in English that are directed to the expertise of the participants in speaking and writing in English. Any task to speak and write using English. The method used is assignment and practice, in which the participants decide to practice English and write in English. English Language Training on the ability of participants to express the idea with words, or ability of a concept, or a certain principle and re-declare with words that are strung together in a sentence.

Keywords: Training, English, Villagers Tigawasa Paket C

\section{PENDAHULUAN}

Tigawasa merupakan desa Bali Aga menghadirkan lingkungan yang terintergrasikan dengan wisata alam dan wisata kerajinan yang ada di dalamnya, termasuk di Desa Tigawasa (Abdurrahman, 2014). Wisata alam tersebut yakni yang berada di Desa Bali Tua. Tentunya pengelolaan objek wisata ini memerlukan sumber daya manusia yang harus dipersiapkan sesegera mungkin. Bahkan tidak jarang wisatawan asing berkunjung ke Tigawasa untuk melihat air terjun singsing yang memesona dan objek wisata lainnya. Tentunya komunikasi dengan menggunakan bahasa asing, terutama Bahasa Inggris sangat diperlukan dalam memberikan pelayanan kepada para wisatawan asing tersebut.

Masyarakat Desa Tigawasa menyadari adanya potensi wisata yang dapat menjadi sebuah produk wisata yang memiliki nilai jual dan memberikan nilai ekonomi. Namun, mereka belum memahami dengan baik apa saja yang harus disiapkan dalam mengelola produk wisata tersebut. Tentunya dari aspek bahasa mereka harus mempersiapkan sumber daya manusianya untuk mampu berkomunikasi dengan baik dalam Bahasa Inggris.

Melihat kenyataan belum adanya pemandu wisata yang mampu berkomunikasi dalam Bahasa Inggris, maka diperlukan sumber daya manusia yang berasal atau bertempat tinggal di Tigawasa untuk memiliki kecakapan berbicara Bahasa Inggris dengan para wisatawan mancanegara. Pelatihan bahasa Inggris diperlukan untuk mempersiapkan warga sekitar yang akan mengurus, mengelola, dan memajukan tempat-tempat wisata yang ada di 
wilayahnya.

Kegiatan pengabdian kepada masyarakat berupa pelatihan Bahasa Inggris ini dilaksanakan di Desa Tigawasa Kecamatan Ciemas Kabupaten Sukabumi. Pelatihan Bahasa Inggris ini diikuti oleh warga Desa Tigawasa yang terdiri dari pelajar Paket $C$ PKBM Widya Aksara Pelatihan bahasa Inggris ini diarahkan pada pencapaian kemampuan berkomunikasi (speaking) dan menulis (writing). Adapun target luaran yang diharapkan dari pelaksanaan pelatihan ini, yaitu para peserta pelatihan memiliki kemampuan berkomunikasi dalam bahasa Inggris, dalam bentuk lisan dan tulisan. Kemampuan berkomunikasi meliputi berbicara (speaking) dan menulis (writing).

Pelaksanaan kegiatan pelatihan bahasa Inggris ini dilakukan dalam beberapa tahap di antaranya, yaitu sosialisasi kegiatan yang bertujuan memberikan gambaran kepada para peserta mengenai program yang akan dilaksanakan dan manfaat yang dapat diperoleh dari kegiatan ini. Mereka diberikan pemahaman apa yang harus dilakukan dalam kegiatan yang akan dilaksanakan dan bagaimana peran mereka dalam kegiatan ini.

Tahap selanjutnya adalah pelatihan bahasa Inggris yang bertujuan untuk meningkatan kemampuan keterampilan bahasa Inggris para peserta, yaitu mengembangkan kemampuan berkomunikasi dalam bahasa Inggris, dalam bentuk lisan dan tulisan. Kemampuan berkomunikasi tersebut meliputi kemampuan berbicara (speaking) dan kemampuan menulis (writing). Pelatihan bahasa Inggris diarahkan ke pencapaian kompetensi yang dapat terlihat dalam kepiawaian peserta melakukan langkah- langkah komunikasi. Sebagai contoh, pelatihan berbicara diarahkan ke keterampilan melakukan dan merealisasi tindak tutur. Ini dimaksudkan agar fokus pelatihan berbicara tidak hanya diarahkan ke tema yang biasa dimaknai dengan berbicara tentang tema tertentu.

Di dalam pelatihan menulis, langkahlangkah komunikasi, seperti mengelaborasi, menambah, mempertajam fokus, menyatakan gagasan utama, menyimpulkan, sebagai langkah-langkah atau pengembangan retorika dalam bahasa tertulis. Sebagai contoh, untuk membuat peserta memproduksi sebuah teks diperlukan tahapan-tahapan produksi yang dimulai dengan melibatkan pengajar dan peserta, diikuti dengan penulisan draft pertama, kemudian dilakukan koreksi oleh pengajar, dilanjutkan dengan penulisan draft kedua dan pengembangan, dan akhirnya peserta sampai ke draft terakhir. Setelah tulisan sesuai dengan yang dikehendaki, peserta pelatihan mengekspos tulisannya agar dapat dibaca oleh peserta lainnya (Departemen Pendidikan Nasional 2008). Kegiatan berbicara ini memberi kesempatan kepada peserta untuk mengungkapkan pendapat dari hasil karyanya. Dengan demikian semua keterampilan berbahasa dapat berkembang secara terpadu.

Tahap terakhir adalah tahap evaluasi yang merupakan kegiatan untuk menilai tingkat keberhasilan dan keberlanjutan kegiatan pengabdian ini. Tahapan evaluasi yang dilaksanakan antara lain:

(1) Mengevaluasi pada saat pelatihan berlangsung, yaitu meliputi pengecekan kehadiran peserta dan pemberian motivasi agar kegiatan ini dapat diikuti dengan baik.

(2) Mengevaluasi pelatihan, yaitu meliputi kegiatan wawancara dan tes sederhana dalam lisan dan tulisan guna mengetahui peningkatan keterampilan peserta pelatihan.

(3) Mengevaluasi hasil pasca pelatihan, yaitu menilai peningkatan kemampuan dan hasil dari pelatihan bahasa Inggris yang diberupa komentar membangun dan saran-saran perbaikan kemampuan bahasa Inggrispeserta.

(4) Adapun pihak yang terlibat dalam kegiatan Pengabdian Pelatihan Bahasa Inggris ini adalah Dosen dan tiga orang mahasiswa peserta KKN yang berasal dari jurusan Sastral nggris.

\section{HASIL DAN PEMBAHASAN}

Bahasa Inggris merupakan alat untuk berkomunikasi secara lisan dan tulisan. Pengertian berkomunikasi dimaksudkan adalah memahami dan mengungkapkan informasi, pikiran, perasaan serta mengembangkan ilmu pengetahuan, teknologi, dan budaya dengan menggunakan bahasa tersebut (Departemen Pendidikan Nasional. 2003).

Pelatihan bahasa Inggris ini bernama English Ten Days Training yang merupakan salah satu program kerja KKN Tematik desa Tigawasa dengan tujuan agar para peserta dapat berkomunikasi dalam bahasa Inggris dengan wisatawan asing yang berkunjung ke objek wisata yang ada di desa Tigawasa. Pelatihan ini diikuti oleh 24 peserta Paket C PKBM Widya aksara sebanyak 24 Orang Pelaksanakannya dimulai dari tanggal 24 Agustus 2015 hingga 4 September 2015 setiap pukul 16.00 sampai selesai yang bertempat di Wisma Desa Tigawasa.

Adapun dalam pelaksanaannya, setiap 
peserta dilatih untuk berbicara dan menulis dengan menggunakan bahasa Inggris. Metode yang digunakan yaitu penugasan dan latihan, dimana para peserta ditugaskan untuk berlatih berbicara bahasa Inggris mengenai percakapan dengan wisatawan asing. Mereka juga ditugaskan untuk menuliskan kembali materimateri percakapan bahasa Inggris yang diberikan serta diberikan motivasi agar lebih percaya diri pada saat berkomunikasi dengan wisatawan asing dalam bahasa Inggris. Kemampuan dasar bahasa Inggris para peserta yang sangat terbatas dalam struktur, tata bahasa, dan kosa kata menyulitkan pengajar dalam mengembangkan materi pembelajaran, Bahasa Inggris para peserta pun sangat terbatas dan kurang bisa merespon serta menyimak dengan baik apa yang diperdengarkan. Upaya yang dilakukan oleh pengajar dalam hal ini adalah melakukan penekankan pada kemampuan peserta menyatakan ide dengan kata-kata, atau kemampuan mengingat suatu konsep, atau prinsip tertentu dan menyatakan kembali dengan kata-kata.

Kemampuan yang diharapkan dapat dicapai dalam proses belajar meliputi kemampuan mengingat dan menyatakan kembali apa yang dipelajari secara bebas dan cepat, kemampuan merangkai kata atau kalimat berdasarkan aturan tertentu, dan kemampuan memasang-masangkan kata, rangkaian kata atau kalimat yang mempunyai hubungan satu sama lain (De Cecco dan Crawford, dalam Sumiati,2007).

Proses pelatihan bahasa Inggris seperti ini menekankan pada keaktifan belajar peserta, melalui latihan yang bersifat praktis. Untuk menunjang keberhasilan latihan, digunakan kata-kata atau bagian kalimat yang diperlihatkan kepada peserta. Praktik latihan dalam belajar berlangsung dengan cara peserta menyatakan kata atau kalimat sesuai dengan konteksnya, atau dengan cara pengajar menyodorkan suatu bentuk kalimat, peserta pelatihan mengganti suatu kata tertentu untuk membuat kalimat dalam bentuk yang lain. Hasilnya, dilihat dari segi kemampuan berbahasa, para peserta pelatihan mendapat kemajuan yang berarti. Pada saat pertemuan pertama, para peserta cenderung lebih pasif. Namun, pada pertemuan selanjutnya para peserta lebih aktif berbicara pada saat pelatihan berlangsung.

\section{SIMPULAN DAN SARAN}

Pelatihan bahasa Inggris warga desa Tigawasa pada dasarnya bertujuan mengembangkan kemampuan berkomunikasi dalam bentuk lisan dan tulisan dan menumbuhkan kesadaran tentang hakikat dan pentingnya bahasa Inggris sebagai salah satu bahasa asing untuk menjadi alat komunikasi dengan wisatawan asing.

Kemampuan yang diharapkan dapat dicapai dalam pelatihan ini meliputi kemampuan berbicara dan menulis dalam bahasa Inggris. Hasil yang ingin dicapai dari pelatihan ini adalah para peserta dapat mengingat dan menyatakan kembali apa yang dipelajari secara tepat, peserta memiliki kemampuan merangkai kata atau kalimat berdasarkan aturan tertentu, dan peserta juga memiliki kemampuan memasangmasangkan kata, rangkaian kata, atau kalimat yang mempunyai hubungan satu sama lain.

\section{DAFTAR RUJUKAN}

Abdurrahman, Oman. 2014. Keragaman Bumi Ciletuh-Jampang. Bandung: Badan Geologi Unpad.

Departemen Pendidikan Nasional. 2003. Kurikulum 2004 Standar Kompetensi Mata Pelajaran Bahasa Inggris SMA dan Madrasah Aliyah. Jakarta: Departemen Pendidikan Nasional

Departemen Pendidikan Nasional. 2008 Bahan/Materi Bintek KTSP SMA Tingkat Kabupaten/Kota. Dirjen Manajemen Pendidikan Dasar dan Menengah dan Direktorat Pembinaan Sekolah Menengah Atas.

Sumiati, Asra. 2007. Metode Pembelajaran. Bandung: $\quad$ CV Wahana Prima. 